Jp.jok (Jurnal Pendidikan Jasmani, Olahraga dan Kesehatan)

http://ejurnal.budiutomomalang.ac.id/index.php/jpjok

Doi : https://doi.org/10.33503/jp.jok.v5i1.1704

\title{
Relationship between Physical Activity and Motor Skills in Elementary School Students: Meta-Analysis Study \\ Muhammad Hamzah Pratama ${ }^{1)}$, Supriatna ${ }^{2)}$, Yulingga Nanda Hanief ${ }^{3)}$ \\ Program Studi Pedidikan Kepelatihan Olahraga \\ Fakultas Ilmu Keolahragaan \\ ${ }^{1,2,3}$ Universitas Negeri Malang, Indonesia \\ Email: ${ }^{1}$ muhammadhamzahpratama1@gmail.com, ${ }^{2}$ supriatna.fik@um.ac.id, 3yulingga.hanief.fik@um.ac.id
}

\begin{abstract}
Many studies that examine physical activity and motor skills have been carried out in sports. These studies explain that physical activity has a very positive effect on improving motor sk ills and athlete performance in all sports. However, the results of each study tend to be different, so it is necessary to carryout inclusive data analysis to provide comprehensive information about the importance of activity in improving athletes' motor skills. This study examines the effect size test of physical activity on motor skills in sports. This study uses a meta-analysis study method. The source of data in this study is Google Scholar. Search literature from various sources using relationships, physical activity, and motor skills. Dataanalysis was carried out th rough the stages of identifying variables, identifying the value of r, transforming the value of rinto a z distribution, the effect size of each study, calculating the variance, calculating the standard error of $z$, and calculating the summary effect. The summary effect calculation uses Jeffreys's Amazing Statistics Program (JASP) software. The final result of this study explains a significant positive correlation between physical activity and motor skills. A correlation value of Random Effect $\left(r_{-} R E\right) 0.8453$ indicates that the relationship between physical activity and motor skills is included in the high category.
\end{abstract}

Keywords: Relationship, Physical Activity, Motor Skills, Early Childhood

\section{Hubungan antara Aktivitas Fisik dengan Keterampilan Motorik pada Siswa Sekolah Dasar: Studi Meta-Analisis}

\begin{abstract}
ABSTRAK
Studiyang menelitiaktivitas fisik dan juga keterampilan motorik sudah banyak dilakukan dalam bidang keolahragaan. Macam-macampenelitian tersebut menjelaskan bahwa aktivitas fisik sangat berpengaruh positif dalampeningkatan keterampilan motorik dan performa atlet disemua cabang olahraga. Akan tetapi hasildari tiap penelitian cenderung berbeda-beda, sehinggga perlu dilakukan analisis data secara inklusif untuk memberikan informasi secara menyeluruh tentang pentingnya aktivitas dalampeningkaan keterampilan motorik atlet. Penelitian ini mengkaji tentang pengujian effect size dari aktivitas fisik terhadap keterampilan motorik dalambidang olahraga. Penelitian ini menggunakan metode studi meta analis is. Sumber data dalampenelitian ini yaitu google scholar. Pencarian literatur dari berbagai sumber menggunakan kata kunci: hubungan, aktivitas fisik, dan keterampilan motorik. Analis is data dilakukan melalui tahapan identifikasi variable, identifikasi nilai $r$, mentransformasi nilai $r$ ke distribusi $\mathrm{z}$ yang merupakan efek size dari setiap studi, menghitung varians, menghitung Standar eror dari $z$, dan menghitung summary effect. Perhitungan summary effect menggunakan software Jeffreys's Amazing Statistics Program (JASP). Hasil akhir dari penelitian ini menjelaskan bahwa terdapat hubungan korelasional positif yang signifikan antara aktivitas fisik dengan keterampilan motorik. Dengan nilai korelasi Random Effect (r_RE) 0,8453, hal ini menunjukkan bahwa hubungan antara aktivitas fisik dengan keterampilan motorik termasuk dalam katagori ting gi.
\end{abstract}

Kata Kunci: Hubungan, Aktivitas Fisik, Keterampilan Motorik, Anak Usia Dini

Info Artikel

Dikirim

Diterima

Dipublikasikan
(C) 2021 IKIP BUDI UTOMO MALANG

P-ISSN 2613-9421

E-ISSN 2654-8003

\footnotetext{
Alamat korespondensi: vulingga.hanief.fik@um.ac.id

Universitas Negeri Malang, Jl. Semarang No.5, Sumbersari, Kec. Lowokwaru, Kota Malang, Jawa Timur 65145 , Indonesia
} 
138 Muhammad Hamzah Pratama ${ }^{1}$, Supriatna ${ }^{2}$, Yulingga Nanda Hanief ${ }^{3)}$.Jp.jok (Jurnal Pendidikan. Jasmani,

Olahraga dan Kesehatan). 5(1) 137-149

\section{PENDAHULUAN}

Olahraga merupakan aktivitas fisik yang sangat digemari masyarakat tidak hanya orang tua,bahkan remaja sampai anak-anak pun sangat antusias dalam melakukan kegiatan fisik. Aktifitas fisik sangat diperlukan bagi perkembangan anak dan juga berperan penting pada tingkat kesehatan anak (Zeng,N , 2017). Selain berdampak dalam peningkatan kesehatan atau peningkatan imunitas tubuh,olahraga juga digunakan dalam peningkatan performa seorang. Organisasi kesehatan moderen mengungkapkan bahwa aktifitas fisik yang tinggi sangat bermanfaat bagi anak segala usia, untuk janga pendek maupun jangka panjang baik dalam peningkatan fisik, kognitif dan emosional anak (Leavitt, 2008; Organization, 2020; Health, 2016). Aktivitas fisik dapat mempengaruhi pertumbuhan fisik dan juga pengoptimalan emosional atlet jika diberikan sesuai pada periode pertumbuhan atlet (Burhaein, 2017). Dalam memaksimalkan suatu performa atlet, peningkatan keterampilan motorik merupakan kunci dalam keberhasilan seorang atlet.

Berbicara tentang aktivitas fisik maka tidak akan lepas dengan keterampilan motorik, semakin baik keterampila motorik seseorang maka semakin baik juga pekerjaan atau aktivitas fisik yang digelutinya (dunia olahraga,kesenian,pekerjaan dan lain sebagainya). Terdapat hubungan yang positif antara keterampilan motorik dengan aktifitas fisik (Logan , Kipling Webster, Getchell, Pfeiffer, \& Robinson, 2015).Keterampilan motorik merupakan suatu kemampuan seseorang dalam peningkatan aktivitas gerak tubuh suatu individu. Dalam kehidupan sehari-hari keterampilan motorik sangatlah penting dalam pengoptimalan aktivitas fisik/olahraga. Individu yang dapat mengembangkan keterampilan motorik sesuai bakat dan potensinya, maka individu tersebut akan berguna dan bermakna bagi diri sendiri maupun bangsa dan negaranya (Mustafa \& Sugiharto, 2020).

Studi yang meneliti aktivitas fisik dan juga keterampilan motorik sudah banyak dilakukan dalam bidang keolahragaan. Macam-macam penelitian tersebut menjelaskan bahwa aktivitas fisik sangat berpengaruh positif dalam peningkatan keterampilan motorik dan performa atlet disemua cabang olahraga. Akan tetapi hasil dari tiap penelitian cenderung berbeda-beda ,hal ini ditegaskan dalam penelitian yang dilakukan oleh Armen dan Rahmalia, hasil penelitian ini memaparkan bahawa pada test medicine ball permainan rondes dan gobak sodor 
dalam meningkatkan gerak motorik kasar adalah tidak signifikan, diperoleh $t_{\text {hitunga }}=0,47<t_{\text {tabel }}=1,67$ dengan taraf signifikansi $5 \%$. Pada test lari 30 meter permainan rondes dan gobak sodor dalam meningkatkan gerak motorik kasar adalah tidak signifikan diperoleh $t_{\text {hitunga }}=1,53<t_{\text {tabel }}=1,67$ dengan taraf signifikansi 5\%. Pada lari bolak-balik 4x5 meter permainan rondes dan gobak sodor dalam meningkatkan gerak motorik kasar adalah signifikan diperoleh $t_{\text {hitunga }}=5,1>t_{\text {tabel }}=1,67$ dengan taraf signifikansi 5\% (Armen \& Rahmalia, 2017). Sehinggga perlu dilakukan analisis data secara inklusif untuk memberikan informasi secara menyeluruh tentang pentingnya aktivitas dalam peningkaan keterampilan motorik atlet. Berdasarkan penjelasan tersebut,maka akan dilakukan penelitian tentang pentingnya aktivitas fisik terhadap peningkatan keterampilan motorik atlet melalui studi meta analisis ,dengan cara menganalisis berbagai kajian penelitian yang pernah dilakukan yang belum dilakukan uji lanjut.

\section{METODE}

Penelitian ini menggunakan metode meta analisis dalam menganalisis data. Meta analisis merupakan serangkaian penelitian yang digunakan untuk review dan merangkum data,dan juga menganalsis penelitian yang pernah dilakukan atau penelitian yang diterbitkan (Anugraheni, 2018). Nama meta-analisis dicetuskan oleh Glass pada tahun 1976 merujuk pada filosofi yang muncul pada setiap pengumpulan bukti data penelitian ilmiah, yang saat ini dikenal sebagai seperangkat prosedural statistik yang banyak digunakan dibidang ilmu pengetahuan dan ilmu sosial yang secara objektif mengasimilasi dan mengukur efek disetiap studi empiris atau studi yang pernah dilakukan dan menghilangkan bias pada sebuah penelitian (Hagger, 2006). Pengembangan teknis sintesis penelitian yang sekarang disebut sebagai meta-analisis merupakan presedur penelitian yang memungkinkan untuk sintesis dan penyulingan sejumlah besar literatur ilmiah menjadi ringkasan yang bermakna dan juga memperhitungkan bias disetiap literatur yang ada (Glass, 2013; Rosenthal \& Rubin, 1982). Meta-analisis sangatlah diperlukan dalam penelitian untuk menilai suatu penelitian yang masih samar-samar kebenarannya dari data yang didapatkan (Balduzzi,Rucker \& Schwarzer, 2019). Penelitian ini bertujuan untuk menguji effect size dari aktivitas 
140 Muhammad Hamzah Pratama ${ }^{1)}$, Supriatna ${ }^{2)}$, Yulingga Nanda Hanief ${ }^{3)}$.Jp.jok (Jurnal Pendidikan. Jasmani,

Olahraga dan Kesehatan). 5(1) 137-149

fisik terhadap keterampilan motorik melalui studi meta-analisis. Effect zise juga disebut statistik atau metrik kunci dalam pencarian data meta analisis,besarnya ukuran effect size mewakili besarnya hubungan dan juga perbedaan antara dua variabel (Hagger, 2006). Effect size ini dapat dinyatakan dalam bentuk skor mentah atau bentuk standart,metrik effect size standart yang sering digunakan adalah koefisien korelasi atau nilai $r$ yang mewakili perbedaan standart antara rata-rata dari dua variabel (Field, 2003). Meta-analisis sangatlah bermanfaat terutama bagi kalangan pendidikan terutama pengajar olahraga yang ingin melakukan peningkatan keterampilan motorik melalui aktivitas fisik siswa tersebut. Langkah-langkah dalam melakukan meta-analisis data yaitu (1) Menentukan dan mempelajari hubungan studi yang akan diteliti, (2) Mengumpulkan study kasus berupa hasil penelitian yang sudah pernah dilakukan sesuai dengan kata kunci, (3) Perhitungan effect size, (4) Mendapati heterogenitas effect size, (5) Penafsiran hasil penelitian data dan kesimpulan (Decoster \& Hall, 2004).

Data penelitian diperoleh dari berbagai sumber literatur berupa jurnal ilmiah teks lengkap yang telah di publikasi ditingkat nasional. Percarian data menggunakan data base google scholar dengan menggunakan kata kunci hubungan,aktivitas fisik,keterampilan motorik dan anak usia dini. Dari penelitian ini didapatkan sebanyak lima populasi data artikel yang didapatkan dari berbagai sumber. Sampel penelitian diambil dengan menggunakan purposive random sampling, yakni pengambilan sampel dengan penggunaan kriteria tertentu. Kriteria yang digunakan peneliti dalam pengambilan sampel data disini menggunakan kriteria inklusi dan esklusi yakni :

1. Artikel bersumber dari google scholar

2. Artikel membahas tentang aktivitas fisik dan keterampilan motorik dalam olahraga yang bersubyekkan anak sekolah dasar (SD) saja

3. Artikel merupakan jurnal nasional yang telah dipublikasikan dan bukan artikel repository ataupun artikel proceeding

4. Artikel yang diambil merupakah artikel full teks yang dapat diakses

5. Artikel diterbit pada tahun 2015-2020, untuk mengetahui kebaruan/tren. 
6. Artikel yang diambil menggunakan stuktur penelitian kuantitatif, khususnya yang menggunakan uji $t$ maupun uji $f$ dalam penelitian datanya.

7. Artikel hanya diambil dari negara indonesia saja

Dari hasil inklusi dan eksklusi data didapatkan sebanyak lima sampel yang memenuhi persyaratan untuk dianalisis, tahap seleksi data dapat dilihat pada gambar berikut :

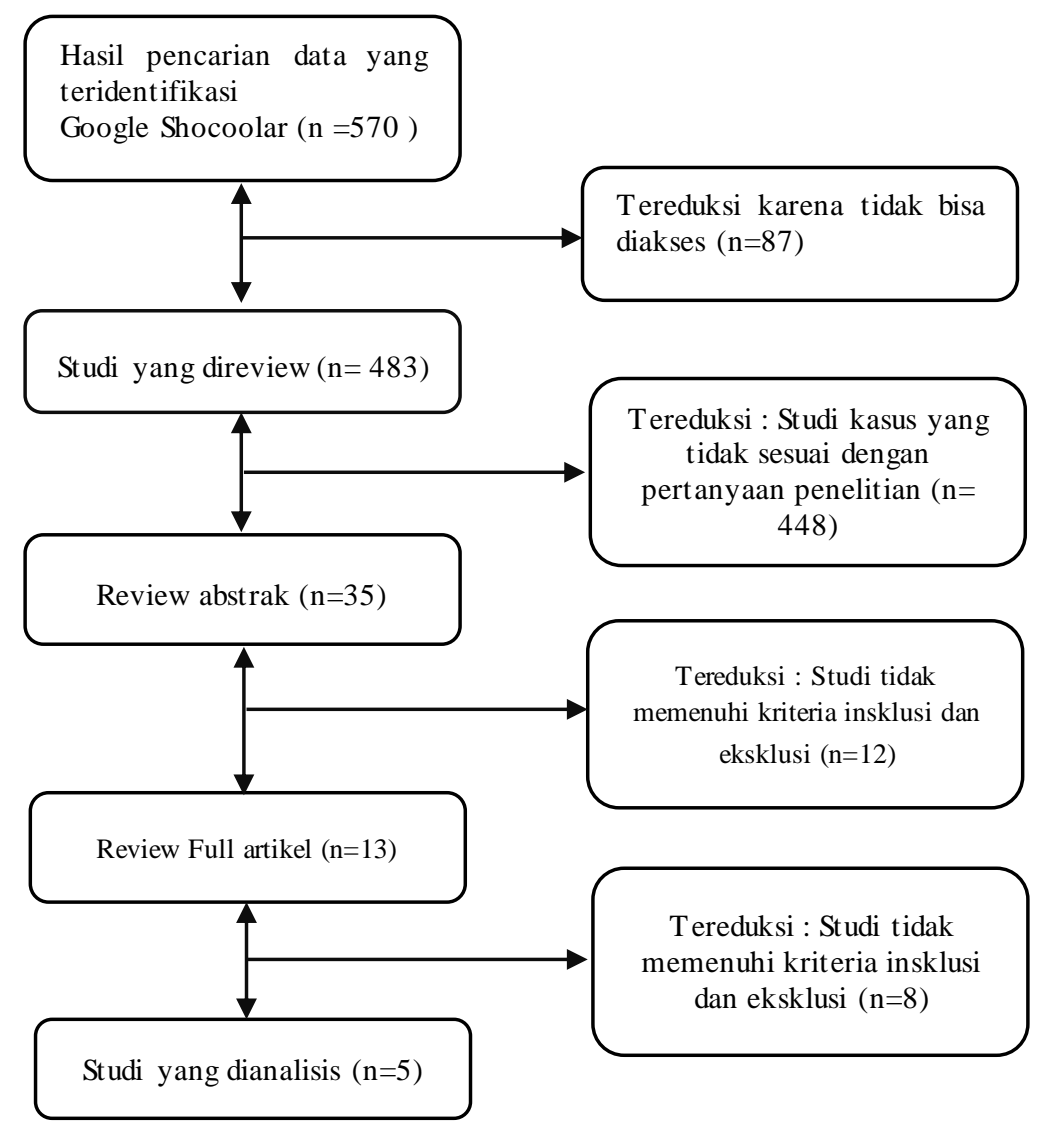

Gambar 1. Diagram alir dalam pengidentifikasian data studi kasus yang memenuhi syarat untuk meta analisis

Jika data sudah ditemukan dari beberapa sumber,maka tahap berikutnya yaitu analisis data, diawali dengan (1) Identifikasi variabel penelitian,data dimasukkan kedalam tabel sesuai kolom variabelnya, (2) identifikasi nilai $r$ pada setiap artikel yang dianalisis. Jika hasil penelitian yang dilaporkan hanya memuat nilai $\mathrm{F}$ atau t, maka ditransformasi ke dalam nilai $\mathrm{r}$, menggunakan persamaan:

1. $F=t^{2}$ 
2. $t=\sqrt{F}$

3. $r=\frac{t}{\sqrt{t^{2}+N-2}}$

(3)mentransformasi nilai $r$ ke distribusi $\mathrm{z}$ yang merupakan efek size dari setiap studi, kemudian menghitung variansnya, (4) menghitung Standar eror dari z, dan (5) menghitung summary effect dari keseluruhan studi (Nuraini, Nafan, Muhlis, Airlangga, \& Java, 2021). Perhitungan summary effect dilakukan menggunakan meta analisis dengan bantuan software Jeffreys's Amazing Statistics Program (). Jeffrey's Amazing Statistics Program (JASP) Version 0.8.5.1 JASP Team(2021).

\section{HASIL DAN PEMBAHASAN}

Tahap selanjutnya adalah tahap studi meta-analisis yang menggunakan datadata penelitian yang sudah lulus dalam tahapan seleksi , sebanyak 565 data tidak memenuhi kriteria inklusi maupun eksklusi untuk dianalisis dari 570 jumlah total data yang diperoleh. Didapatkan sebanyak sembilan data penelitian yang siap dilanjutkan untuk dianalisis yang diperoleh dari berbagai sumber database yang digunakan yaitu Google Scholar. Studi yang akan dianalisis disajikan didalam tabel 1 berikut.

Tabel 1. Studi Data Yang Akan Dilakukan Meta-Analisis

\begin{tabular}{|c|c|c|c|c|c|}
\hline No & Penulis/Tahun & $\begin{array}{c}\text { Karakte ris tik } \\
\text { sampel }\end{array}$ & $\mathbf{N}$ & $\begin{array}{c}\text { Variabel } \\
\text { Pengukur }\end{array}$ & $\mathbf{r}$ \\
\hline 1 & $\begin{array}{l}\text { (Nur,Giyartini \& } \\
\text { Sumardi, 2020) }\end{array}$ & $\begin{array}{l}\text { Anak SD } \\
\text { Laboratorium } \\
\text { Tasikmalaya }\end{array}$ & 20 & $\begin{array}{l}\text { Outbound } \\
\text { Activities }\end{array}$ & 0,9887 \\
\hline 2 & $\begin{array}{l}\text { (Prasetya \& } \\
\text { Komaini, 2019) }\end{array}$ & $\begin{array}{l}\text { Anak SDN } \\
\text { 166/III Cutmutia } \\
\text { Kerinci }\end{array}$ & 12 & $\begin{array}{c}\text { Permainan } \\
\text { Tradisional } \\
\text { Terhadap Lari } 30 \\
\text { Meter }\end{array}$ & 0,7029 \\
\hline 3 & $\begin{array}{l}\text { (Prasetya \& } \\
\text { Komaini, 2019) }\end{array}$ & $\begin{array}{l}\text { Anak SDN } \\
\text { 166/III Cutmutia } \\
\text { Kerinci }\end{array}$ & 12 & $\begin{array}{l}\text { Permainan } \\
\text { Tradisional } \\
\text { Terhadap } \\
\text { Kelincahan }\end{array}$ & 0,7167 \\
\hline 4 & $\begin{array}{l}\text { (Prasetya \& } \\
\text { Komaini, 2019) }\end{array}$ & $\begin{array}{l}\text { Anak SDN } \\
\text { 166/III Cutmutia } \\
\text { Kerinci }\end{array}$ & 12 & $\begin{array}{c}\text { Permainan } \\
\text { Tradisional } \\
\text { Terhadap Daya } \\
\text { Power Tungkai }\end{array}$ & 0,6882 \\
\hline 5 & $\begin{array}{l}\text { (Armen \& } \\
\text { Rahmalia, 2017) }\end{array}$ & $\begin{array}{l}\text { Siswa kelas V } \\
\text { SDN } 16 \text { Surau } \\
\text { Gadang }\end{array}$ & 54 & $\begin{array}{c}\text { Permainan } \\
\text { Tradisional } \\
\text { Rondes Dan }\end{array}$ & 0,0650 \\
\hline
\end{tabular}




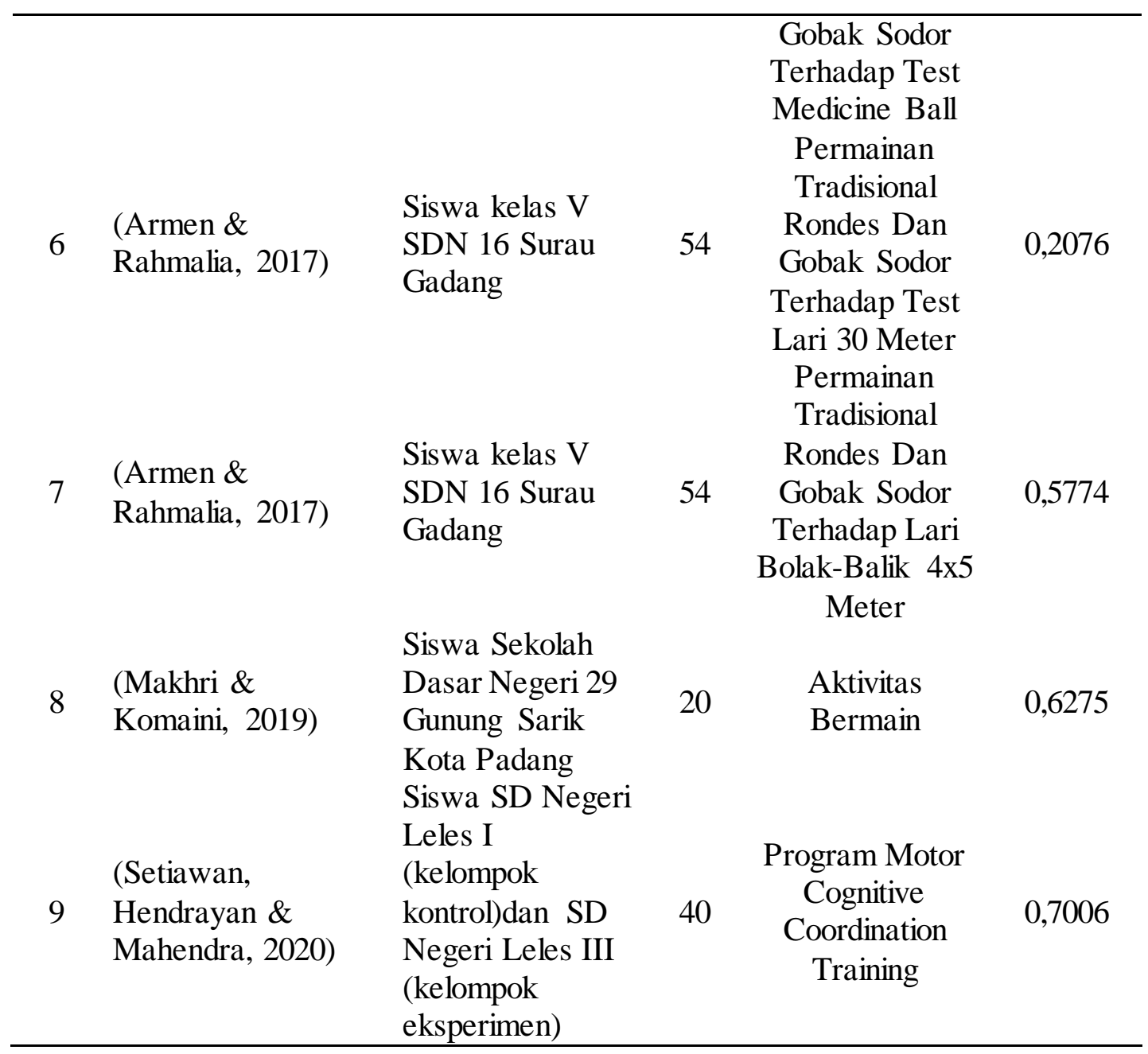

Selanjutnya dilakukan uji heterogenitas untuk mengetahui apakah ada ketidaksamaan varian dari residual untuk semua pengamatan pada model regresi yang dapat ditunjukkan pada tabel 2 berikut.

Tabel 2. Fixed and Random Effects

\begin{tabular}{lrrr}
\hline & $\mathrm{Q}$ & $\mathrm{df}$ & $\mathrm{p}$ \\
\hline Omnibus test of Model Coefficients & 12,17 & 1 & $<.001$ \\
Test of Residual Heterogeneity & 94,09 & 8 & $<.001$
\end{tabular}

Note. $p$-values are approximate.

Data pada tabel 2 menunjukkan studi data effect size yang dianalisis dinyatakan heterogen $(\mathrm{Q}=94,09, \mathrm{p}<0,001)$. Hasil data tersebut menunjukkan model Random Effect lebih cocok digunakan untuk memperkirakan rerata effect 
144 Muhammad Hamzah Pratama ${ }^{1)}$, Supriatna ${ }^{2}$, Yulingga Nanda Hanief ${ }^{3)}$.Jp.jok (Jurnal Pendidikan. Jasmani, Olahraga dan Kesehatan). 5(1) 137-149

size dari sembilan studi yang dianalisis. Dengan begitu dari penelitian ini dapat ditarik kesimpulan bahwa terdapat potensi besar variabel yang saling berhubungan antara aktivitas fisik dengan keterampilan motorik. Pengujian summary effect (Tabel 3) digunakan untuk menghitung tingkat korelasi antara aktivitas fisik dengan keterampilan motorik anak berdasarkan nilai korelasi random effect.

Tabel 3. Confficients

95\% Confidence Interval

\begin{tabular}{lccccc}
\hline Estimate & $\begin{array}{c}\text { Standard } \\
\text { Error }\end{array}$ & $z$ & $p$ & $\begin{array}{c}\text { Lower } \\
\text { Bound }\end{array}$ & $\begin{array}{r}\text { Upper } \\
\text { Bound }\end{array}$ \\
\hline $\begin{array}{l}\text { intrcpt } \\
\text { Note. Wald test. }\end{array}$ & 0,2423 & 3,4883 & $<.001$ & 0,3704 & 1,3203 \\
\hline
\end{tabular}

Analisis menggunakan random Effect pada tabel 3 menyatakan bahwa terdapat korelasional yang positif dan signifikan antara aktivitas fisik dengan keterampilan motorik siswa $(\mathrm{z}=3,4883, p<0,001,95 \% \mathrm{CI},(0,3704 ; 1,3203)$. Ada juga hubungan antara aktivitas fisik dengan keterampilan motorik siswa termasuk pada katagori tinggi $\left(\boldsymbol{r}_{\boldsymbol{R}}=0,8453\right)$ (Cohen, 1992).

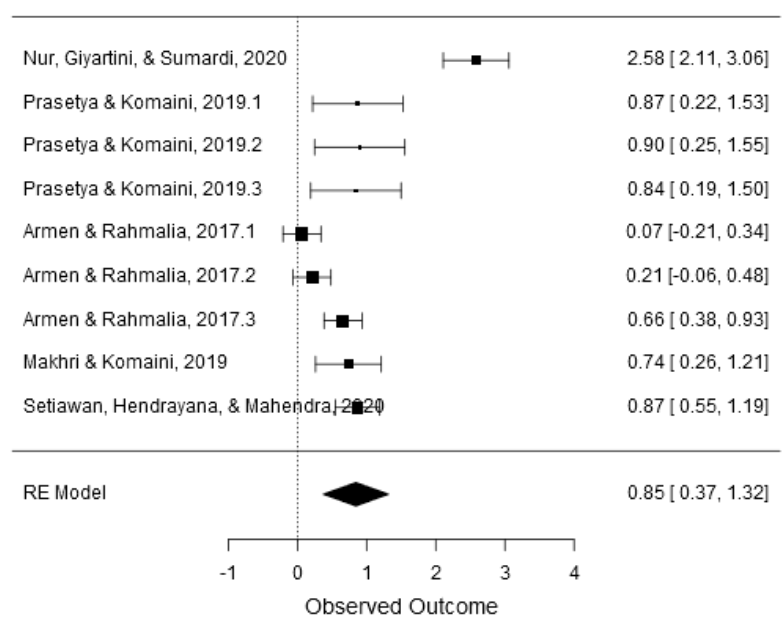

Gambar 2. Forest Plot Penyebaran Effect Size

Berdasarkan diagaram Forest Plot pada gambar 2 dapat ditarik kesimpulan bahwa efect size studi yang diteliti beragam antara 0,07 hingga 2,58. Selanjutnya analisis bias publiasi (Gambar 3) dilakukan untuk mengetahui ada tidaknya bias pada setiap studi-studi yang dianalisis. 


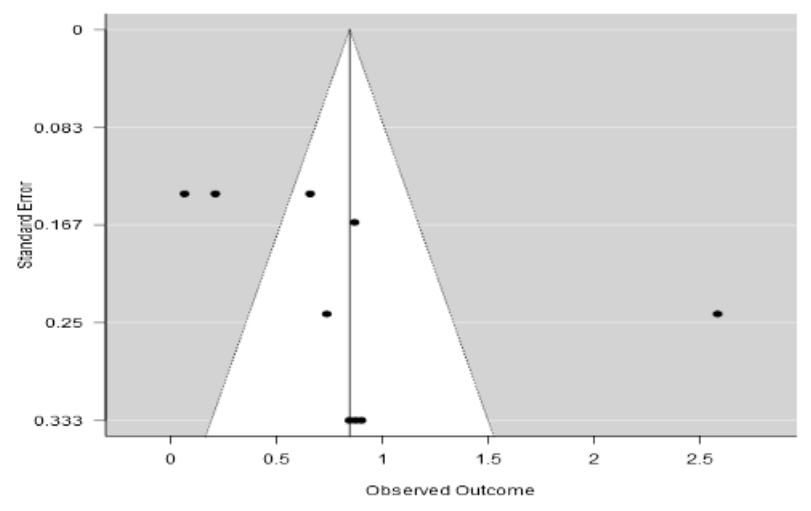

Gambar 3. Funnel Plot Hasil Analisis

Hasil dari analisis Funnel Plot (Gambar 3) susah untuk memastikan simetris atau tidaknya Funnel Plot, maka dari itu dibutuhkan uji Egger's Test untuk mengetahui funnel plot simetris atau tidak yang ditunjukkan pada tabel 4 berikut.

Tabel 4. Regression Test For Funnel Plot Asymmetry (Egger's Test)

\begin{tabular}{lll}
\hline & $\mathrm{z}$ & $\mathrm{p}$ \\
\hline Sei & 1.0382 & 0.299 \\
\hline
\end{tabular}

Dari hasil Egger's test pada tabel 4, nilai $\mathrm{p}>0,05$ yang menunjukkan bahwa nilai Funnel Plot adalah simetris. Maka dapat dipastikan bahwa tidak terdapat bias publikasi pada studi meta analisis tersebut. Selanjutnya dilakukan file drawer analisis yang ditunjukkan pada tabel 5 berikut.

Tabel 5. File Drawer Analysis

\begin{tabular}{llll}
\hline & Fail safe N & $\begin{array}{l}\text { Target } \\
\text { Significance }\end{array}$ & $\begin{array}{l}\text { Observed } \\
\text { Significance }\end{array}$ \\
\hline Rosenthal & 406 & 0,050 & $2,9098 \mathrm{e}-29$ \\
\hline
\end{tabular}

Hasil file drawer analisis pada tabel 5 menunjukkan bahwa $\mathrm{K}=9$, maka $5 \mathrm{~K}+10=5(9)+10=55$. Nilai fail safe $-N$ yang didapatkan 406 , dengan target signifikan 0,050 dan $\mathrm{p}>0,001$. Karena nilai fail-safe $N>5 \mathrm{~K}+10$, dari sini dapat ditarik kesimpulan bahwa tidak terdapat bias publikasi pada studi meta analisis.

Aktivitas Fisik merupakan salah satu faktor penunjang perkembangan motorik anak. Ketika fisik anak berkembang dengan baik kemungkinan anak akan dapat mengembangkan keterampilan fisiknya dan juga dapat mengeksplorasi lingkungan tanpa bantuan orang lain (Leonardo \& Komaini, 2021). Kurangnya aktifitas fisik atau kurang gerak dapat berpengaruh pada tingkat kesehatan anak. 
146 Muhammad Hamzah Pratama ${ }^{1)}$, Supriatna ${ }^{2)}$, Yulingga Nanda Hanief ${ }^{3)}$.Jp.jok (Jurnal Pendidikan. Jasmani,

Olahraga dan Kesehatan). 5(1) 137-149

Jika seseorang kurang melakukan aktivitas fisik maka tubuh hanya mengeluarkan sedikit energi, ketika pemasukan energi tidak diimbangi dengan pengeluaran yang setara maka dapat berpotensi pada obesitas atau kegemukan (Leonardo \& Komaini, 2021). Melakukan aktifitas fisik secara rutin dapat mencegah kegemuakan atau obesitas dan penyakit degeneratif seperti hipertensi, penyakit jantung, diabetes mellitus, osteoporosis, kanker dan lain sebagainya (Heryudarini, 2013). Dari hasil analisis diatas dapat dilihat sesungguhnya terdapat hubungan yang signifikan dan positif antara aktivitas fisik dengan keterampilan motorik, dengan nilai korelasional Random Effect $\left(\boldsymbol{r}_{\boldsymbol{R} E}\right)$ 0,8453 dapat di interpretasikan bahwa dua variabel ini memiliki hubungan dengan kategori tinggi yang artinya yakni semakin tinggi aktivitas fisik anak, maka semakin baik pula keterampilan anak tersebut (Audina \& Sutapa, 2020).

Hasil dari penelitian ini juga memperkuat gagasan penelitian sebelumnya, yakni proses peningkatan keterampilan motorik didapatkan dari kegiatan fisik melalui berlari dan melompat (Prasetya \& Komaini, 2019). Keterampilan motorik anak awalnya terdapat pada proses kematangan, proses belajar, dan pengalaman saat anak melakukan aktivitas fisik (Septiani \& Nadar, 2019). Penelitian yang dilakukan oleh Sezici \& Akkaya (2020) memaparkan bahwa anak-anak harus memiliki keterampilan motorik kasar dan keterampilan motorik halus, guna untuk perkembangan awal anak prasekolah. Di era pandemi covid-19 ini perkembangan motorik anak menjadi masalah yang serius, dengan sistem pembelajarin daring membuat pengajar harus memiliki variasi pembelajaran yang tepat agar dapat menunjang perkembangan motorik peserta didiknya (Brian \& Taunton, 2018). Meskipun hasil analisis bias publikasi didalam gambar diagram funnel plot tidak dapat ditunjukkan dengan jelas dan spesifik ,tetapi analisis egger's test dan fail save $N$ menunjukkan tidak terdapat bias publikasi. Hal ini menunjukkkan bahwa studi meta analisis data yang dilakukan pada hubungan antara aktivitas fisik dan keterampilan motorik dapat diterima sebagai data yang tidak samar dan sesuai kondisi terkini. 


\section{SIMPULAN}

Ditandai dengan nilai korelasi Random Effect yang termasuk dalam kategori tinggi, dari sini dapat dijelaskan bahwa tidak terdapat bias publikasi data tetapi ditemukan hubungan yang signifikan dan korelasional positif antara aktivitas fisik dengan keterampilan motorik.

Penulis menyarankan kepada guru dan orang tua siswa untuk terus mengimplementasikan physical literacy dalam kehidupan sehari-hari agar perkembangan motorik anak dapat berkembang secara baik dan maksimal.Bagi peneliti diharapkan untuk penelitian selanjutnya dapat menganalisis penelitian dengan variabel selain aktifitas fisik.

Keterbatasan penelitian ini juga adalah database yang digunakan hanya Google Schoolar dan artikel yang dianalisis hanya artikel yang terbit di jurnal nasional. Penelitian selanjutnya diharapkan dapat menganalisis artikel dari berbagai database seperti Scopus, Elsevier, maupun Web of Science.

\section{DAFTAR RUJUKAN}

Anugraheni, I. (2018). Meta Analisis Model Pembelajaran Problem Based Learning dalam Meningkatkan Keterampilan Berpikir Kritis di Sekolah Dasar. Polyglot, 14(1), 9-18. Retrieved from http://dx.doi.org/10.19166/pji.v14i1.789

Armen \& Rahmalia. (2017). Pengaruh Permainan Tradisional Rondes Dan Gobak Sodor Terhadap Kemampuan Gerak Motorik Kasar Siswa Kelas V SD. UNES Journal of Education, 1(4), 324-330.

Audina \& Sutapa. (2020). Permainan Halang Rintang untuk Meningkatkan Motorik Kasar Pada Anak Usia Dini yang Mengalami Obesitas. Jurnal Pendidikan Anak, 6(1), 30-37. Retrieved from http://jurnal.fkip.unila.ac.id/index.php/PAUD/artic le/view/20864

Balduzzi,Rucker \& Schwarzer. (2019). How to perform a meta-analysis with R: A practical tutorial. Evidence-Based Mental Health, 22(4), 153-160. http://dx.doi.org/10.1136/ebmental-2019-300117

Brian \& Taunton. (2018). Effectiveness of motor skill intervention varies based on implementation strategy. Physical Education and Sport Pedagogy, 23(2), 222-233. http://dx.doi. org/10.1080/17408989.2017.1413709 
148 Muhammad Hamzah Pratama ${ }^{1)}$, Supriatna ${ }^{2)}$, Yulingga Nanda Hanief ${ }^{3)}$.Jp.jok (Jurnal Pendidikan. Jasmani, Olahraga dan Kesehatan). 5(1) 137-149

Burhaein, E. (2017). Aktivitas Fisik Olahraga untuk Pertumbuhan dan Perkembangan Siswa SD. Indonesian Journal of Primary Education, 1(1), 51. http://dx.doi.org/10.17509/ijpe.v1i1.7497

Cohen, J. (1992). Current Directions in Psychological Science. Sage Juornal, 1, 98. http://dx.doi.org/10.1111/1467-8721.ep10768783

Decoster \& Hall. (2004). Meta-Analysis Notes. Narrative.

Field, A. P. (2003). The Problems in Using Fixed-Effects Models of MetaAnalysis on Real-World Data. Understanding Statistics, 2(2), 105-124. doi:https ://doi.org/10.1207/S15328031US0202_02

Glass, G. V. (2013). Primary, Secondary, and Meta-Analysis of Research. Educational Researcher, 5(10), 3-8. Retrieved from http://www.jstor.org/stable/1174772

Health, N. I. (2016). Benefits of Physical Activity. Retrieved from https://www.nhlbi.nih.gov/health/health-topics/topics/ phys/benefits.

Hagger, M. S. (2006). Meta-analysis in sport and exercise research: Review, recent developments, and recommendations. European Journal of Sport Science, 6(2), 103-115. doi:10.1080/17461390500528527

Heryudarini, H. (2013). Pola Aktivitas Fisik Anak Usia 6,0-12,9 Tahun Di Indonesia. Gizi Indonesia, 36(2), 99-108.

Leavitt, M. O. (2008). 2008 Physical Activity. Health (San Francisco). Retrieved from www.health.gov/paguidelines

Leonardo, A., \& Komaini, A. (2021). Hubungan Aktivitas Fisik Terhadap Keterampilan Motorik. Jurnal Stamina, 4(3), 135-144. Retrieved from stamina.ppj.unp.ac.id

Logan , S., Kipling Webster, E., Getchell, N., Pfeiffer, K. A., \& Robinson, L. E. (2015). Relationship Between Fundamental Motor Skill Competence and Physical Activity During Childhood and Adolescence: A Systematic Review. Kinesiology Review, 4(4), 416-426. doi:10.1123/kr.2013-0012

Makhri \& Komaini. (2019). Hubungan Aktivitas Bermain dan Status Gizi dengan Kemampuan Motorik Siswa Sekolah Dasar Negeri 29 Gunung Sarik Kota Padang. JURNAL STAMINA, 2(3), 121-128. Retrieved from http:/stamina.ppj. unp.ac.id/index.php/JST/article/view/359

Mustafa \& Sugiharto. (2020). Keterampilan Motorik Pada Pendidikan Jasmani Meningkatkan Pembelajaran Gerak Seumur Hidup. Sporta Saintika, 5(2), 199-218. http://dx.doi. org/10.24036/sporta.v5i2.133 
Nur,Giyartini \& Sumardi. (2020). Gross motor skills: Outbound Activities in Elementary Students. JUARA: Jurnal Olahraga, 5(1), 9399.https://doi.org/10.33222/juara.v5i1.781

Organization, W. H. (2020). Physical Activity. Retrieved from https://www.who.int/news--room/fact-sheets/detail/physical-activity.

Prasetya \& Komaini. (2019). Pengaruh Permainan Tradisional terhadap Peningkatan Kemampuan Motorik Kasar pada Siswa Putra Sekolah Dasar Negeri 166/III Cutmutia Kerinci. Jurnal Stamina, 2(6), 65-78. Retrieved from http//stamina.ppj. unp.ac.id/index.php/JST/article/view/415

Rosenthal, R., \& Rubin, D. B. (1982). Comparing Effect Sizes of Independent Studies. 2, 500-504. doi: 10.1037//0033-2909.92.2.500

Septiani \& Nadar. (2019). Upaya Meningkatkan Motorik Kasar melalui Bermain Lempar Tangkap Bolar Retrieved from http:/jurnal.stkipkusumanegara.ac.id/index.php/semnara2019/article/view/23 6

Setiawan, Hendrayan \& Mahendra. (2020). Pengaruh program motor cognitive coordination training terhadap gross motor skill dan working memory dalam pendidikan jasmani. Jurnal Penelitian Ilmu Pendidikan, 13(2), 94-109. https://doi.org/10.21831/jpipf ip.v13i2.29279

Sezici \& Akkaya. (2020). The effect of preschool children's motor skills on selfcare skills. Early Child Development and Care, 190(6), 963-970. http://dx.doi.org/10.1080/03004430.2020.1737040

Zeng et al,N . (2017). Effects of Physical Activity on Motor Skills and Cognitive Development in Early Childhood: GCU Library Resources - All Subjects. $\begin{array}{llll}\text { BioMed Research } \quad \text { International, } & \text { 2017, }\end{array}$ doi:https ://doi.org/10.1155/2017/2760716 